\title{
Suitability for Consumption of Chyawanprakash-A Herbal Formulation in Controlled Type II Diabetics-A Open Label Clinical Study
}

\author{
Satyendra Kumar ${ }^{1 *}$, Arun Gupta ${ }^{1}$, Raman Ghungralekar ${ }^{2}$ and Vaishali Shailesh Deshpande ${ }^{3}$ \\ ${ }^{1}$ Medical Affairs and Clinical Research Division, Dabur Research and Development Centre, Dabur India Limited, Uttar Pradesh, India \\ ${ }^{2}$ Department of Kayachikitsa, R A Podar Medical (Ayurvedic) College and M A Podar hospital, Mumbai, Maharashtra, India \\ ${ }^{3}$ Department of Kayachikitsa, Sumatibhai Shah Ayurved Mahavidyalya, Malwadi, Mumbai Pune, Maharashtra, India
}

*Corresponding author: Satyendra Kumar, Medical Affairs and Clinical Research Division, Dabur Research and Development Centre, Dabur India Limited, Uttar Pradesh, India, Tel: 9650535899; E-mail: satyendra.kumar@mail.dabur

Received date: November 30, 2016; Accepted date: January 30, 2017; Published date: February 02, 2017

Copyright: @ 2017 Kumar S. This is an open-access article distributed under the terms of the Creative Commons Attribution License, which permits unrestricted use, distribution, and reproduction in any medium, provided the original author and source are credited.

\begin{abstract}
Objective: Chyawanprakash, a Chyawanprash based proprietary Ayurvedic formulation in which conventional sugar and honey are replaced by permitted alternate sweeteners in diabetic population.

Design: This was a randomized open label clinical study conducted across two study sites in Maharashtra (India). 121 male and female subjects in the age range of 18-70 years who were suffering from Type II Diabetes mellitus for more than one year and were stabilized on either exercise/diet regimen or oral hypoglycemic agents were recruited in the study and advised 1 teaspoonful of Chyawanprakash twice daily orally after meals for 90 days. They were advised to continue their anti-diabetic medicines under the supervision of the Investigator. Results were assessed basis pre and post treatment changes in glycosyated hemoglobin (HbA1c) and the Physician global assessment of overall safety. Clinical symptoms, laboratory parameters like blood sugar and insulin levels, microalbuminuria, liver and renal function tests, lipid profiles etc and changes in dose of oral hypoglycemic agents were also assessed.
\end{abstract}

Results: Oral administration of Chyawanprakash in recommended dosage in controlled Type II diabetics did not show any safety concern which was evident by no statistically significant change in $\mathrm{HbA} 1 \mathrm{c}$ levels and the clinical as well as laboratory parameters (blood sugar, microalbuminuria, liver and renal function tests, lipid profiles etc). $97 \%$ excellent safety was reported on the Physician's global assessment of overall safety. Moreover, a statistically significant improvement was also observed in energy levels of subjects.

Conclusion: Results concluded the suitability of Chyawanprakash in controlled Type II diabetics.

Keywords: Ayurveda; Diabetes; Herbal; Sugar free; Suitability; HbAlc

\section{Introduction}

The prevalence of diabetes mellitus in India is predicted to double globally from 171 million in 2000 to 366 million in 2030 posing a significant health care burden [1,2]. Patients with diabetes mellitus have infections more often than those without DM. The course of the infections is also more complicated in this patient group. One of the possible causes of this increased prevalence of infections is poor immunity $[3,4]$.

Ayurveda has suggested rejuvenative therapies or the Rasayanas for leading a healthy and active life. Modern pharmacology interprets Rasayana as a product having antioxidant, immunomodulatory, antistress and nootropic properties and the one promoting health [5]. Chyawanprash is an Ayurvedic Rasayana formulation used in Indian traditional medicinal system for its beneficial effect on human health viz.; maintaining youth, vigour and vitality [6,7] via antioxidant and immunostimulatory actions $[8,9]$. However, its use in diabetic population is restricted due to sugar contents.
Chyawanprakash is Chyawanprash based proprietary product. Though, Chyawanprash is renowned as a time tested immunity booster, its use in diabetic population is restricted due to its sugar contents. Chyawanprakash is Chyawanprash based product in which sugar and honey are replaced by sorbitol and sucralose. It is intended to be used by people with diabetes irrespective of treatment regimen. Sorbitol is a nutritive sweetener providing dietary energy and often used in diet foods and cough syrups [10]. Sucralose is no-calorie sweetener, safe for consumption by diabetics as it does not affect blood glucose level [11]. Previously, safety of Chyawanprakash has been established in animal model via 28 day repeated dose oral toxicity study [12]. In another study, Chyawanprakash at doses of $1.2 \mathrm{~g} / \mathrm{Kg}$ did not show significant effect on blood glucose levels in non-diabetic and streptozotocin induced diabetic animals when compared to the nondiabetic vehicle control [13]. The current study conducted between the years 2013-2014 aimed to establish the clinical safety and suitability for consumption of Chyawanprakash in controlled Type II diabetic patients.

\section{Objective}

Suitability assessment of Chyawanprakash in controlled Type 2 diabetics. 
Citation: Kumar S, Gupta A, Ghungralekar R, Deshpande VS (2017) Suitability for Consumption of Chyawanprakash-A Herbal Formulation in Controlled Type II Diabetics-A Open Label Clinical Study. Altern Integr Med 6: 230. doi:10.4172/2327-5162.1000230

Page 2 of 8

\section{Primary outcomes}

1. Assessment of pre and post treatment changes in glycosylated hemoglobin $(\mathrm{HbA} 1 \mathrm{c})$ values.

2. Post-treatment Physician global assessment of overall safety of Chyawanprakash

\section{Secondary outcomes}

1. Monthly assessment of changes in fasting and postprandial plasma glucose levels, adverse drug reactions, clinical symptoms of diabetes (polyuria, polydipsia, polyphagia and fatigue), changes in microalbuminuria, changes in dose of OHAs and the Quality of Life
2. Assessment of changes in pre and post treatment of serum insulin levels in fasting state

3. Assessment of post-treatment clinically significant abnormal laboratory parameters

\section{Material and Methods}

\section{Study product}

Chyawanprakash (Mfd. Dabur India Limited), Batch No. PN0201 and PN0189, Mfd.11/2012, was used in the present study. The composition details of Chyawanprakash are given in Table 1.

\begin{tabular}{|c|c|}
\hline Contents* & Quantity (g) \\
\hline Pterocarpus marsupium & 3.52 \\
\hline $\begin{array}{l}\text { Aegle marmelos, Premna integrifolia, Oroxylum indicum, Stereospermum suaveolens, Gmelina arborea, Desmodium gangeticum, Uraria } \\
\text { picta, Vitis vinifera, }\end{array}$ & \\
\hline $\begin{array}{l}\text { Solanum indicum, Solanum xanthocarpum, Tribulus terrestris, Phaseolus trilobus, Teramnus labialis, Pistacia integerrima, Phyllanthus niruri, } \\
\text { Inula racemosa, Aquilaria agallocha, Terminalia chebula, Tinospora cordifolia, Curcuma zedoaria, Cyperus rotundus, Boerhavia verticillata, } \\
\text { Nymphaea stellata, Adhatoda vasica, Glycyrrhiza glabra, Maritima annua, }\end{array}$ & 0.38 \\
\hline Sida cordifolia & 0.684 \\
\hline Leptadenia reticulata & 0.076 \\
\hline Dioscorea bulbifera & 0.76 \\
\hline Asparagus racemosus & 0.76 \\
\hline Withania somnifera & 0.76 \\
\hline Pueraria tuberosa & 1.14 \\
\hline Emblica officinalis & 82.0 \\
\hline Sesamum indicum & 0.82 \\
\hline Clarified butter & 0.91 \\
\hline Bambusa bambos & 1.34 \\
\hline Piper longum & 1.84 \\
\hline Cinnamomum zeylanicum & 0.194 \\
\hline Elettaria cardamomum & 1.008 \\
\hline Cinnamomum tamala & 0.205 \\
\hline Mesua ferrea & 0.190 \\
\hline Syzygium aromaticum & 0.212 \\
\hline Glycyrrhiza glabraGlabra & 1.0 \\
\hline \multicolumn{2}{|l|}{${ }^{*}$ Each $100 \mathrm{~g}$ of Chyawanprakash } \\
\hline
\end{tabular}

Table 1: Composition details of Chyawanprakash.

\section{Study design}

Current trial was an open labeled, prospective, and interventional, Phase III clinical study conducted across two sites in Maharashtra, India viz.; (1) R.A. Podar Medical (Ayurvedic) College \& M.A. Podar Hospital, Worli, Mumbai and (2) Sumatibhai Shah Ayurved Mahavidyalya, Malwadi, Hadapsar, Pune; through an independent
CRO. The study was conducted with prior approval from respective Institutional Ethics Committees, and in accordance with GCP guidelines, the ICMR ethical guidelines for biomedical research on human participants and Declaration of Helsinki. The clinical study was registered with the Clinical Trial Registry of India (CTRI) on $15 / 04 / 2013$. The CTRI number for the study is CTRI/2013/04/003553. 


\section{Inclusion criteria}

Male and female subjects in the age range of 18-70 years, suffering from Type II Diabetes mellitus for more than one year, and stabilized on diet and exercise regimen or mono/polydrug anti-diabetic therapy/ oral hypoglycemic agents (OHA). In addition, patients who had their fasting blood glucose level in a range of $90-150 \mathrm{mg} / \mathrm{dl}$ and postprandial glucose in the range of $110-180 \mathrm{mg} / \mathrm{dl}$, HbAlC below $8 \%$, and ECG not demonstrating any signs of uncontrolled arrhythmia/acute ischemia and X-ray chest not showing any active lesion of tuberculosis at screening visit were included.

Female subjects who entered the study were either non-pregnant or at least six weeks postpartum and non-lactating. A urine pregnancy test was done for all the female subjects of childbearing potential unless subject had had a hysterectomy, tubal ligation, or was $>2$ years postmenopausal. All the recruited subjects were willing to follow the study procedures and had voluntarily signed an informed consent form.

\section{Exclusion criteria}

Subjects on insulin therapy, Subjects suffering from Type I Diabetes or other than Type II Diabetes, known major complications of diabetes like ketoacidosis, nephropathy, neuropathy, retinopathy and diabetic wounds or hepatic/renal/ significant cardiovascular disease event $<12$ weeks prior to randomization, active metabolic or gastrointestinal diseases excluding diabetes that may interfere with nutrient absorption, metabolism or excretion, active malignancy, contagious infectious diseases such as active tuberculosis, Hepatitis B or C or HIV, subjects using any other investigational drug within 1 month prior to recruitment, known hypersensitivity to any of the ingredients used in study drug, participating in another clinical study, pregnancy, lactation or any other condition due to which patients were deemed to be unsuitable by the investigator for reason(s) not specifically stated in the exclusion criteria.

\section{Study visits}

Subjects were called to the study center for visits on every 15 th day till 90 days from the baseline visit. The visit schedule was- Screening Visit (Day-5), Baseline Visit (Day 0), Visit 1(Day 15), Visit 2 (Day 30), Visit 3 (Day 45), Visit 4 (Day 60), Visit 5 (Day 75) and Visit 6 (Day 90).

\section{Methodology}

Controlled Type II diabetics attending the outpatient clinic of respective sites were screened for eligibility criteria. On screening visit, a written informed consent was obtained from subjects for their participation in the study. Subject's history was recorded and their physical examination was carried out. Clinical symptoms of diabetes viz.; polyuria, polydipsia, polyphagia and fatigue were assessed and graded on clinical symptom scoring scale.

Subjects who fulfilled all the inclusion and exclusion criteria were screened on day -5 ( 5 days before baseline) where subject's venous blood $8-10 \mathrm{ml}$ fasting and $2 \mathrm{ml}$ post prandial (one and half hour post meal) samples and fasting urine sample were collected for estimation of fasting and postprandial plasma sugar levels. If fasting blood sugar was between 90 to $150 \mathrm{mg} / \mathrm{dl}$ and postprandial blood glucose was between the ranges of $110-180 \mathrm{mg} / \mathrm{dl}$, then $\mathrm{HbAlc} \%$ was estimated. If the value of $\mathrm{HbAlc} \%$ was below $8 \%$, then CBC, ESR, $\mathrm{Hb} \%$, microalbuminuria, serum insulin (fasting state), Liver and Renal function Tests, Lipid profile, routine and microscopic examinations of urine, Urine pregnancy test (only if the subject was female of child bearing potential) and HIV test (I \& II) were carried out. If all the lab investigations were within the prescribed limits, subject's X- ray chest (PA View) and ECG were done. If X-ray and ECG were within normal limits, then, the subject was recruited in the study (baseline visit) if he/she met all the inclusion and none of the exclusion criteria.

\section{Intervention and treatment duration}

A container containing $900 \mathrm{~g}$ of Chyawanprakash was given to subjects at baseline visit, on day 30 and 60. Subjects were advised 1 teaspoonful of Chyawanprakash orally twice daily after meals for 90 days continuing their anti-diabetic medicines (OHAs) under the supervision of the investigator. They were advised to continue the diabetic diet and exercise regimen (which they had been following) during the entire study period. Drug compliance was assessed at every follow-up visit.

\section{Statistical analysis}

Mean differences of continuous variables were examined by paired ' $t$ ' test to evaluate if there was any statistically significant difference between the values at the initial visit and subsequent follow up visits or the final visit. All p-values were reported based on two-sided significance test and all the statistical tests were interpreted at $5 \%$ level of significance level. Safety analysis was done of all the subjects who had been administered at least one dose of Chyawanprakash.

\section{Evaluation analysis}

Subjects underwent general and systemic examinations and Subject's Quality of life was evaluated on WHO Quality of Life Questionnaire at the baseline visit. Drug compliance, general and systemic examinations and assessment of clinical symptoms of Type II DM were carried out at every visit. Assessment of dose of OHAs and Quality of life on WHO Quality of Life Questionnaire was done on monthly basis. If required, the dose of OHAs was reduced or increased by investigator after assessing subject's blood sugar levels. Subject's Fasting and PP blood sugar levels, microalbuminuria were checked every month. Overall safety of the study drug was assessed by the investigator and by the subject at the end of the study. All the subjects were closely monitored for any Adverse Events starting from baseline visit till the end of the study visit. All laboratory parameters were assessed initially and at day 90 . After completion of 90 days of study treatment, all the subjects were asked to stop study medication and take advice of investigator for further treatment.

\section{Results}

A total of 151 subjects suffering from DM were screened, 121 subjects were recruited of which 101 completed the study. Twenty subjects dropped out prematurely due loss to follow up. No adverse event was reported by any of the dropped out subjects. Maximum patients $(22.77 \%)$ enrolled in the study were in the age range of 61-65 years followed by $56-60$ years $(21.78 \%)$. The Male: Female ratio in the study was 37:64. The participant flow chart for the study is shown in Figure 1.

The Prakriti or Ayurvedic phenotype-based constitution of subjects showed majority Pitta-kaphaj phenotypes (Table 2). 
Citation: Kumar S, Gupta A, Ghungralekar R, Deshpande VS (2017) Suitability for Consumption of Chyawanprakash-A Herbal Formulation in Controlled Type II Diabetics-A Open Label Clinical Study. Altern Integr Med 6: 230. doi:10.4172/2327-5162.1000230

Page 4 of 8

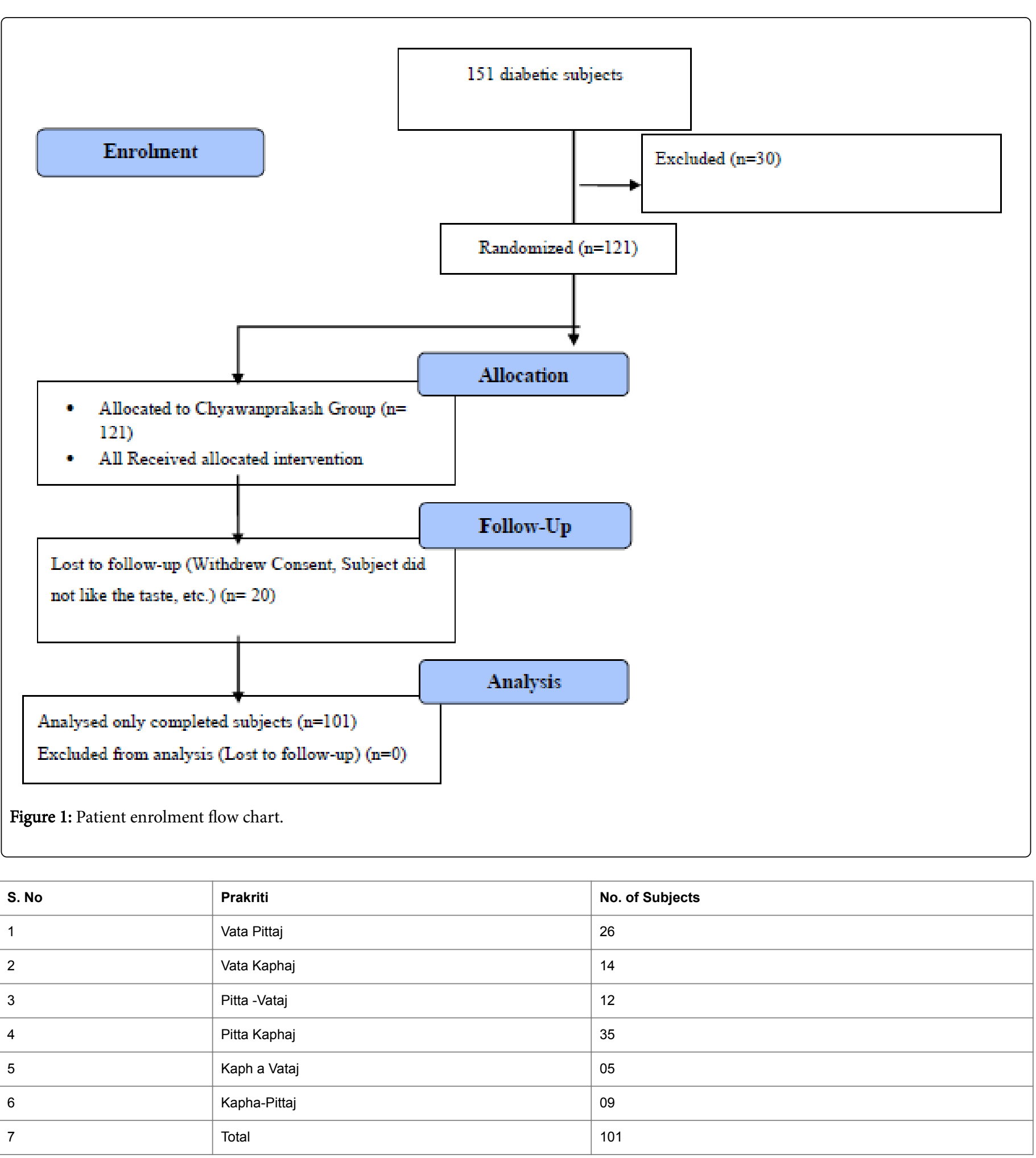

Table 2: Prakriti wise distribution of subjects.

\begin{tabular}{|l|l|l|}
\hline Parameter & Baseline Visit (0 day) & Visit VI (Day 90) \\
\hline HbAlc\% & $6.94 \pm 0.69$ & $7.03 \pm 0.94$ \\
\hline
\end{tabular}


Citation: Kumar S, Gupta A, Ghungralekar R, Deshpande VS (2017) Suitability for Consumption of Chyawanprakash-A Herbal Formulation in Controlled Type II Diabetics-A Open Label Clinical Study. Altern Integr Med 6: 230. doi:10.4172/2327-5162.1000230

Page 5 of 8

\begin{tabular}{|l|l|l|}
\hline Serum insulin & $6.51 \pm 4.72$ & $9.38 \pm 7.21^{*}$ \\
\hline *Significant $p<0.05$ & & \\
\hline
\end{tabular}

Table 3: Effect on glycosylated Hemoglobin (HbA1c\%) values.

\section{Efficacy Assessment}

Initially the mean $\mathrm{HbA1c} \%$ value was 6.94 , while at the end of the study it was found to be 7.03 , showing a statistically non-significant change $(\mathrm{p}<0.05$, Table 3$)$. The mean values of fasting and PP blood sugar at baseline did not show any statistical difference at the end of the study (Table 4). The mean serum insulin value was 6.51 , which increased significantly $(\mathrm{p}<0.05)$ to 9.38 at the end of the study. This increase was, however, within the normal range of serum insulin. The mean increase in microalbuminuria level was non- significant from 13.69 at baseline to 17.05 at the end of the study. The mean body weight, hemoglobin and ESR values did not show any statistically significant difference at the end of the study (Table 5).

Statistically significant reduction $(\mathrm{p}<0.05)$ in the symptoms of diabetes such as polydipsia, polyphagia and fatigue were observed at the end of the study. Polyuria, however, showed a statistically significant increase $(p<0.05)$ at the end of the study (Table 6). There was no change in most of the questions of WHO QOL from baseline visit to the end of the study visit. However, statistically significant improvement $(\mathrm{p}<0.05)$ was observed in energy level from baseline to end of the study visit (Table 7).

The biochemical laboratory parameters including Cholesterol, Triglycerides (TG), Low Density Lipoprotein (LDL), High density lipoprotein (HDL), Very Low Density Lipoprotein, TC/HDL, LDL/ HDL, Serum Creatinine, BUN/Creatinine, Serum Uric Acid, Serum Calcium, SGOT, SGPT and bilirubin (direct and indirect), serum alkaline phosphate, total protein, serum globulin, serum albumin/ globulin, were done at the initial visit and at the end of 90 days. There were significant change in serum SGOT, alkaline phosphate, albumin and LDL levels and the Albumin/ Globulin and the LDL/HDL ratio. These changes were, however, in the normal reference range at both these visits (Tables 8-11). Almost 95\% subjects did not require their oral hypoglycemic medications or doses to be increased from exiting medication that they were taking. Patients who were stabilized on diet and exercise continued to do the same and there was no need to introduce OHA for diabetes management.

\begin{tabular}{|l|l|l|l|l|}
\hline Blood Sugar & $\begin{array}{l}\text { Baseline Visit } \\
\text { (Day 0) }\end{array}$ & $\begin{array}{l}\text { Visit II (Day 30) } \\
\text { (Mean } \pm \text { SD) }\end{array}$ & $\begin{array}{l}\text { Visit IV (Day 60) } \\
\text { (Mean } \pm \text { SD) }\end{array}$ & Visit VI (Day 90) (Mean \pm SD) \\
\hline Fasting & $104.75 \pm 19.96$ & $105.87 \pm 22.45$ & $113.09 \pm 45.54$ & $109.61 \pm 35.11$ \\
\hline Post prandial & $143.19 \pm 26.15$ & $142.68 \pm 35.57$ & $158.23 \pm 50.93$, & $153.02 \pm 52.30$ \\
\hline Micro albumin urea & $13.69 \pm 16.83$ & $13.73 \pm 17.12$ & $17.31 \pm 30.21$ & $17.05 \pm 29.14$ \\
\hline
\end{tabular}

Table 4: Effect on fasting and post prandial blood sugar.

\begin{tabular}{|l|l|l|l|}
\hline S. No. & Parameters & Baseline ( Day 0) (Mean \pm SD) & Visit VI( Day 90) (Mean \pm SD) \\
\hline 1 & Body Weight & $61.88 \pm 9.37$ & $61.87 \pm 9.49$ \\
\hline 2 & Hemoglobin \% & $12.36 \pm 1.58$ & $12.24 \pm 1.81$ \\
\hline 3 & ESR & $22.00 \pm 16.67$ & $24.42 \pm 17.76$ \\
\hline
\end{tabular}

Table 5: Effect on body weight, Hemoglobin\% and ESR.

\begin{tabular}{|c|c|c|c|c|c|c|c|}
\hline Symptoms & Baseline & Visit I & Visit II & Visit III & Visit IV & Visit V & Visit VI \\
\hline Polyuria & $0.34 \pm 0.59$ & $0.37 \pm 0.59$ & $0.36 \pm 0.61$ & $0.36 \pm 0.56$ & $0.31 \pm 0.50$ & $0.29 \pm 0.50$ & $0.46 \pm 0.66$ * \\
\hline Polydypsia & $0.52 \pm 0.74$ & $0.56 \pm 0.74$ & $0.60 \pm 0.73^{*}$ & $0.46 \pm 0.62$ & $0.46 \pm 0.64$ & $0.40 \pm 0.61$ & $0.22 \pm 0.41^{* *}$ \\
\hline Polyphasia & $0.36 \pm 0.59$ & $0.40 \pm 0.63$ & $0.24 \pm 0.46$ & $0.21 \pm 0.41$ & $0.2 \pm 0.40^{* *}$ & $0.22 \pm 0.425$ * & $0.15 \pm 0.38^{* *}$ \\
\hline Fatigue & $0.41 \pm 0.62$ & $0.35 \pm 0.61$ & $0.28 \pm 0.58^{* *}$ & $0.27 \pm 0.54$ & $0.19 \pm 0.42$ ** & $0.20 \pm 0.42^{* *}$ & $0.15 \pm 0.38^{* *}$ \\
\hline
\end{tabular}

Table 6: Mean change in symptoms of diabetes at each follow up. 
Citation: Kumar S, Gupta A, Ghungralekar R, Deshpande VS (2017) Suitability for Consumption of Chyawanprakash-A Herbal Formulation in Controlled Type II Diabetics-A Open Label Clinical Study. Altern Integr Med 6: 230. doi:10.4172/2327-5162.1000230

Page 6 of 8

\begin{tabular}{|c|c|c|c|c|c|c|c|}
\hline Visit & $\begin{array}{l}\text { How Would you } \\
\text { rate your } \\
\text { quality of } \\
\text { life? }\end{array}$ & $\begin{array}{l}\text { How satisfied are } \\
\text { you } \\
\text { with your } \\
\text { health? }\end{array}$ & $\begin{array}{l}\text { To what extent do } \\
\text { you feel that } \\
\text { physical pain } \\
\text { prevents you } \\
\text { from doing what } \\
\text { you need } \\
\text { to do? }\end{array}$ & $\begin{array}{l}\text { Do you have } \\
\text { enough energy } \\
\text { for everyday } \\
\text { life? }\end{array}$ & $\begin{array}{l}\text { How satisfied are } \\
\text { you with your } \\
\text { sleep }\end{array}$ & $\begin{array}{l}\text { How satisfied } \\
\text { are you with } \\
\text { your ability to } \\
\text { perform your } \\
\text { daily living } \\
\text { activities? }\end{array}$ & $\begin{array}{l}\text { How satisfied are } \\
\text { you with your } \\
\text { capacity for } \\
\text { work? }\end{array}$ \\
\hline Baseline & $3.7 \pm 0.46$ & $3.67 \pm 0.59$ & $3.7+0.86$ & $3.28+0.67$ & $3.54 \pm 0.83$ & $3.76+0.47$ & $3.72 \pm 0.49$ \\
\hline $\begin{array}{l}\text { Final } \\
\text { Visit }\end{array}$ & $3.7 \pm 0.50$ & $3.76 \pm 0.51$ & $3.86 \pm 0.80$ & $3.42 \pm 0.57^{* *}$ & $3.56 \pm 0.76$ & $3.78 \pm 0.50$ & $3.8 \pm 0.45$ \\
\hline
\end{tabular}

Table 7: WHO QOL reading at baseline and final visits.

\begin{tabular}{|c|c|c|}
\hline Visits & Baseline visit (Day 0 \} & Visit VI (Day 90) \\
\hline Total Cholesterol & $187.43 \pm 45.87$ & $193.14 \pm 42.51$ \\
\hline Triglycerides & $136.30 \pm 75.00$ & $139.54 \pm 77.33$ \\
\hline HDL & $47.37 \pm 11.39$ & $47.82 \pm 11.37$ \\
\hline LDL & $102.57 \pm 40.59$ & $134.29 \pm 39.43^{*}$ \\
\hline VLDL & $25.99 \pm 13.24$ & $27.07 \pm 14.93$ \\
\hline $\mathrm{TC} / \mathrm{HDL}$ & $4.05 \pm 1.01$ & $4.09 \pm 1.06$ \\
\hline LDL/HDL & $2.20 \pm 0.80$ & $2.41 \pm 0.81^{*}$ \\
\hline
\end{tabular}

Table 8: Effect on lipid profile.

\begin{tabular}{|c|c|c|}
\hline Visits & Baseline visit (Day 0 & Visit VI (Day 90) \\
\hline Total Bilirubin & $0.61 \pm 0.30$ & $0.58 \pm 0.25$ \\
\hline Direct Bilirubin & $0.177 \pm 0.058$ & $0.172 \pm 0.056$ \\
\hline Indirect Bilirubin & $0.44 \pm 0.26$ & $0.413 \pm 0.214$ \\
\hline SGOT & $25.49 \pm 7.69$ & $23.37 \pm 7.65^{\star *}$ \\
\hline SGPT & $21.83 \pm 9.19$ & $22.47 \pm 11.36$ \\
\hline Alkaline Phosphate & $98.64 \pm 28.86$ & $94.74 \pm 30.16^{*}$ \\
\hline Total Protein & $7.77 \pm 0.48$ & $7.71 \pm 0.44$ \\
\hline Serum Albumin & $4.29 \pm 0.25$ & $4.37 \pm 0.28$ * \\
\hline Serum Albumin/ Globulin & $1.25 \pm 0.21$ & $1.33 \pm 0.20$ \\
\hline
\end{tabular}

Table 9: Effect on liver functions.

\begin{tabular}{|l|l|l|}
\hline Visits & Baseline visit \{Day O) & Visit VI (Day 90) \\
\hline BUN & $11.42 \pm 4.05$ & $10.86 \pm 4.03$ \\
\hline S. Creatinine & $0.68 \pm 0.18$ & $0.67 \pm 0.18$ \\
\hline
\end{tabular}


Citation: Kumar S, Gupta A, Ghungralekar R, Deshpande VS (2017) Suitability for Consumption of Chyawanprakash-A Herbal Formulation in Controlled Type II Diabetics-A Open Label Clinical Study. Altern Integr Med 6: 230. doi:10.4172/2327-5162.1000230

Page 7 of 8

\begin{tabular}{|l|l|l|}
\hline BUN/CREATININE & $16.90 \pm 4.36$ & $16.22 \pm 4.77$ \\
\hline S. URIC ACID & $4.99 \pm 1.26$ & $4.87 \pm 1.29$ \\
\hline S. CALCIUM & $9.54 \pm 0.64$ & $9.45 \pm 0.40$ \\
\hline *Significant $p<0.05,{ }^{*}$ Significant $p<0.01$ & \\
\hline
\end{tabular}

Table 10: Effect of drug on renal profile.

\begin{tabular}{|l|l|l|l|}
\hline Usage of OHAs & $\begin{array}{l}\text { Baseline Visit } \\
\text { (Day 0) }\end{array}$ & $\begin{array}{l}\text { Visit II } \\
\text { (Day 30) }\end{array}$ & $\begin{array}{l}\text { Visit IV } \\
\text { (Day 60) }\end{array}$ \\
\hline Not taking any OHA & $11(10.89 \%)$ & $8(7.92 \%)$ & $11(10.89 \%)$ \\
\hline Taking single OHA & $25(24.75 \%)$ & $30(29.70 \%)$ & $22(21.78 \%)$ \\
\hline Taking combination OHA & $65(64.36 \%)$ & $63(62.38 \%)$ & $68(67.33 \%)$ \\
\hline
\end{tabular}

Table 11: Effect on oral hypoglycemic agents (oha) usage.

\section{Safety Assessment}

Of the 101 subjects who completed the study, none of the patients had any severe adverse event (SAE). Only 4 patients complained of mild adverse events like fullness of abdomen, mild pain in abdomen, skin rashes in Chyawanprakash group, however, none of the event is related to study product. These events resolved at their own and did not require stopping the intervention or administration of any medication.

The overall safety of the study drug was graded on global assessment scale by the investigator and by subject as excellent/good/fair or poor overall safety. As per physician's opinion, $97 \%$ subjects reported overall excellent safety and 3\% reported overall good safety. As per patients' opinion, 94\% subjects reported overall excellent safety and 6\% reported overall good safety. Excellent compliance and tolerability to Chyawanprakash was observed in completed subjects. It was observed that even after consumption of Chyawanprakash for 3 months, their diabetic conditions did not worsen.

Chyawanprash is an age old formulation described in classical Ayurvedic texts due to beneficial effects on human health. It comprises multiple Ayurvedic ingredients which possess rejuvenating, strength promoting, nourishing and antioxidant properties. The beneficial effects of Chyawanprash have been mentioned in authoritative Ayurvedic literature like the Compendium of Charaka (Charaka Samhita), Bhaishajyaratnavali and The Ayurvedic Formulary of India that are mentioned in first schedule of The Drug \& Cosmetic Act, 1940 of India. As per Charaka Samhita and The Ayurvedic Formulary, Chyawanprash is beneficial in various respiratory conditions, weakness and debility, in improving the quality of life and as a rejuvenator. It is also reported to exhibit immunomodulatory properties [6-9]. Chyawanprakash is a Chyawanprash based Ayurvedic Rasayana formulation intended to be used by people with diabetes in which sugar is replaced by sorbitol and sucralose. Ingredients of Chyawanprakash like Asana (Pterocarpus marsupium Roxb.) [14], Bilva (Aegle marmelos (L.) Corrêa) [15], Tvak (Cinnamomum zeylanicum Blume) [16], Kachura (Curcuma zedoaria (Christm.) Roscoe) [17], Amla (Phyllanthus emblica L.) [18] and Tejapatra (Cinnamomun tamala Nees.) [19] etc. are traditionally known and have been reported to possess antidiabetic properties. Herbs and replacement of sugar and honey by sorbitol and sucralose in Chyawanprakash may have contributed to its effects. Further studies to evaluate the effects of Chyawanprakash in different Ayurvedic phenotypes may be carried out in future studies

\section{Conclusion}

Oral administration of Chyawanprakash in recommended dosage in Type II controlled diabetics did not show any safety concern which was evident by no statistically significant change in clinical parameters as well as laboratory parameters like blood sugar, HbAlc, microalbuminuria, liver function tests, renal function tests, lipid profiles etc. A statistically significant improvement was observed in energy levels of subjects. Results concluded the suitability of Chyawanprakash in Type II diabetic patients controlled by Oral Hypoglycemic Agents.

\section{References}

1. Joshi SR, Parikh RM (2007) India - diabetes capital of the world: now heading towards hypertension. J Assoc Physicians India 55: 323-324.

2. Kaveeshwar SA, Cornwall J (2014) The current state of diabetes mellitus in India. Australias Med J 7: 45-48.

3. Deresinski S (1995) Infections in the diabetic patient: Strategies for the clinician. Infect Dis Rep 1: 1-12.

4. Geerlings SE, Hoepelman AI (1999) Immune dysfunction in patients with diabetes mellitus (DM). FEMS Immunol Med Microbiol 26: 259-265.

5. Govindarajan R, Vijayakumar M, Pushpangadan P (2005) Antioxidant approach to disease management and the role of Rasayana herbs of Ayurveda. J Ethnopharmacol 99: 165-178.

6. Sastri K, Chaturvedi GN (2011) Agnivesha. Charaka Samhita of Aginivesa. Rasayanadhikara. Varanasi (India): Chaukhambha Bharati Academy, pp.16-18.

7. The Ayurvedic Formulary of India, Part I Vol.1. Ministry of Health and Family Welfare, Govt. of India.

8. Madaan A, Kanjilal S, Gupta A, Sastry JLN, Verma R, et al. (2015) Evaluation of immunostimulatory activity of Chyawanprash using in vitro assays. Indian J Experimental Biol 53: 158-163.

9. Sastry JLN, Gupta A, Brindavanam NB, Kanjilal S, Kumar S, et al. (2014) Quantification of Immunity Status of Dabur Chyawanprash - A Review Part- 2 (Clinical Studies). Indian J Applied Res 4: 205-211. 
Citation: Kumar S, Gupta A, Ghungralekar R, Deshpande VS (2017) Suitability for Consumption of Chyawanprakash-A Herbal Formulation in Controlled Type II Diabetics-A Open Label Clinical Study. Altern Integr Med 6: 230. doi:10.4172/2327-5162.1000230

Page 8 of 8

10. Campbell F (2011) Biochemistry International Edition, 7th Edn, Publisher Brooks/Cole.

11. Grotz VL, Henry RR, McGill JB, Prince MJ, Shamoon H, et al. (2003) Lack of effect of sucralose on glucose homeostasis in subjects with type 2 diabetes. J Am Diet Assoc 103: 1607-1612.

12. Singh P, Wahid S, Jha KK (2010) 28-Days Repeated Dose toxicity Study of DRDC/AY/8048 (Dabur Chyawanprakash) in Wistar Rats by Oral Route. Data on files, Althea Lifesciences Limited. New Delhi, India, pp. 1-22.

13. Mani K, Sakat S, Goswami G (2011) Role on test item on blood glucose level using non diabetic and experimentally induced diabetic rats. Data on files, Althea Lifesciences Limited, New Delhi, India, pp. 1-26.

14. Devgan M, Nanda A, Ansari SH (2013) Comparative evaluation of the anti-diabetic activity of Pterocarpus marsupium Roxb. heartwood in alloxan induced diabetic rats using extracts obtained by optimized conventional and non conventional extraction methods. Pak J Pharm Sci 26: 973-976.

15. Panaskar SN, Joglekar MM, Taklikar SS, Haldavnekar VS, Arvindekar AU (2013) Aegle marmelos Correa leaf extract prevents secondary complications in streptozotocin-induced diabetic rats and demonstration of limonene as a potent antiglycating agent. J Pharm Pharmacol 65: 884-894.

16. IM K, Issac A, NM J, Ninan E, Maliakel B, et al. (2014) Effects of the polyphenol content on the anti-diabetic activity of Cinnamomum zeylanicum extracts. Food Funct 5: 2208-2220.

17. Rahmatullah M, Azam NK, Pramanik S, Jahan R (2012) Antihyperglycemic activity Evaluation of Rhizomes of Curcuma zedoaria (Christm.) Roscoe and Fruits of Sonneratia caseolaris. Internat J PharmTech Res 4: 125-129.

18. Fatima N, Hafizur RM, Hameed A, Ahmed S, Nisar M, et al. (2015) Ellagic acid in Emblica officinalis exerts anti-diabetic activity through the action on $\beta$-cells of pancreas. Eur J Nutr [Epub ahead of print].

19. Kumar S, Vasudeva N, Sharma S (2012) GC-MS analysis and screening of antidiabetic, antioxidant and hypolipidemic potential of Cinnamomum tamala oil in streptozotocin induced diabetes mellitus in rats. Cardiovasc Diabetol 11: 95. 